\title{
KARŞILAŞTIRMALI İHRACAT
}

\section{PERFORMANSI (CEP) İNDEKSINE}

GÖRE TÜRKIYE'NİN AB28 ADAY

\section{ÜLKELERİ KARŞISINDAKİ REKABET}

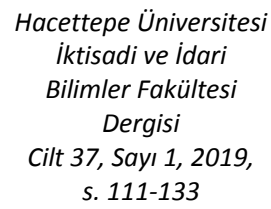

s. $111-133$

\section{GÜCÜ (2006-2016)}

\author{
Nurdan KUŞAT \\ Doç.Dr., Isparta Uygulamalı Bilimler \\ Üniversitesi \\ Isparta Meslek Yüksek Okulu \\ Dıș Ticaret Bölümü \\ nurdankusat@isparta.edu.tr
}

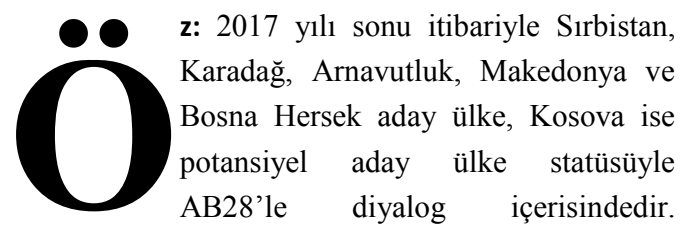

Çalışmada AB'ye tam üyelik başvurusu yaklaşık 60 yıla ulaşan Türkiye'nin, bu aday ülkeler karşısındaki karşılaştırmalı ihracat performansı seçilmiş bazı sektörler çerçevesinde hesaplanmaktadır. $\mathrm{Bu}$ hesaplamada Donges vd.'nin 1982 yılında geliştirdiği "Karşılaştırmalı İhracat Performansı" (Comparative Export Performance-CEP) indeksi'nden yararlanılmaktadır. Çalışmanın tarih aralığı 2006-2016 ve sektörler imalat, tarım, gıda, tekstil, demir çelik ve kimyasallar sektörleri şeklinde belirlenmiştir. Elde edilen bulgular Türkiye'nin tekstil sektöründeki ihracat performansını ve rekabet gücünü teyit ederken; imalat sektöründe Makedonya, tarım ve gıda sektörlerinde Karadağ ve Surbistan, demir çelik sektöründe Makedonya ve Arnavutluk, Kimyasallar sektöründe ise Makedonya ve Sirbistan yüksek ihracat performansları ve rekabet avantajları ile dikkat çekmektedir.

Anahtar Sözcükler: Karşılaştırmalı ihracat performansı, rekabet gücü, rekabet avantajı, $A B$ aday ülkeleri. 


\section{TURKEY'S COMPETITIVENESS}

\section{AGAINST EU28 CANDIDATE \\ COUNTRIES ACCORDING TO THE Journal of Economics and Administrative Sciences \\ Vol. 37, Issue 1, 2019 pp. 111-133}

Hacettepe University COMPARATIVE EXPORT PERFORMANCE (CEP) INDEX (2006-2016)

\author{
Nurdan KUŞAT \\ Assoc.Prof.Dr., Isparta University of \\ Applied Sciences \\ Isparta Vocational School \\ nurdankusat@isparta.edu.tr
}

bstract: By the end of 2017, Serbia,
Montenegro, Albania, Macedonia and
Bosnia and Herzegovina which have
candidate country status and Kosovo which a potential candidate country status are in dialogue with the EU28. The comparative export performance of Turkey, which has reached its application for full membership to the EU approximately 60 years, is calculated on the basis of selected sectors against these countries in our work. In this calculation, the "Comparative Export Performance" (CEP) index developed by Donges et al. in 1982 is utilized. The date range of the study is 2006-2016 and sectors are defined as manufacturing, agriculture, food, textile, iron and steel and chemicals. While the findings confirm Turkey's export performance and competitiveness in the textile sector, Macedonia in the manufacturing sector, Montenegro and Serbia in the agriculture and food sectors, Macedonia and Albania in the iron and steel sector, Macedonia and Serbia in the chemicals sector attract attention with their high export performance and competitive advantages.

Keywords: Comparative export performance, competitiveness, competitive advantage, EU candidate countries. 


\section{GíRIŞ}

2016 yll itibariyle tüm dünya ülkelerinin toplam mal ihracat1 15.985 .000 milyon \$ değerinde olup, AB28 ülkeleri bu tutarın yaklaşı \%34'ünü (5.379.330 milyon \$) gerçekleştirerek dünya ihracatındaki liderliğini ortaya koymuştur. Aynı yıl itibariyle 16.229.000 milyon \$'lık dünya ithalat değerinin yaklaşı \%33'lük kısmı (5.342.585 milyon \$) bu ülke grubu tarafindan gerçekleştirilmiş ve AB28 ülkeleri ithalatta da liderlik konumunu bir başka ekonomik topluluğa ya da ülkeye bırakmamıştır.

AB28 ülkelerinin dünya ticaretindeki bu ağıllıklı yapısı, bu ekonomik birlik ile dış ticaret yapan ve yapmayı arzulayan ülkeler için bir ayrıcalık oluşturmaktadır. Bunu bir ayrıcalık olarak değerlendirmemizde, AB28 ülkelerinin kendi iç ticaretlerinin dünya ticareti içerisindeki payının ağırlıklı bir yapı oluşturmasının rolü büyüktür. Nihayetinde; AB28 ülkelerinin toplam ihracatı içerisinde AB28 içi ihracatı (2016 y1lı verilerine göre) ${ }^{1,2}$ yaklaşık \%64, ithalatı ise yaklaşık \%65 oranında bir yer kaplamaktadır (WTO, 2017)

AB28 ülkelerinin gerek dünya ticaretinde, gerekse kendi içlerinde gerçekleştirdikleri ticaretlerinde bu kadar yoğun bir yapı ortaya koymaları ve 21.yy itibariyle genişlemeci bir politika izlemeye başlamaları, özellikle doğu Avrupa'daki dönüşüm ekonomileri için bir kalkınma fırsatı yaratmaktadır. Bu çerçevede özellikle Yugoslavya'nın parçalanmasıyla ortaya çıkan küçük Avrupa ülkeleri bu durumun farkına vararak, ekonomik anlamda güçlü olan bu yapılanmanın içerisinde yer almalarının bir zorunluluk olduğu düşüncesiyle $\mathrm{AB}$ 'ye üyelik başvurusunda bulunmaya başlamışlardır. Bu bağlamda Makedonya 2005, Karadağ 2010, Sırbistan 2012, Arnavutluk 2014 ve Bosna Hersek 2016 yıllarında AB'ye aday ülke statüsüyle kabul edilmişlerdir. Fakat Bosna Hersek'in halen potansiyel aday statüsü tam olarak kalkmamıştır. Kosova ise bağımsızlığını ilan eden en son ülke olması yanında, adaylık sürecinde de diğer ülkelerin gerisinde kalmış ve halen adaylığı onaylanmamakla birlikte, potansiyel aday ülke konumunda $\mathrm{AB}$ ile ilişkilerini sürdürmektedir. Türkiye ise 1959 yılında başlayan tam üyelik sürecini, nihayet 1999 yılında aday ülke statüsüne çıkarabilmiştir.

Bu çalışma ile yeni ekonomik düzenin en önemli getirisi olan serbest dış ticaretin ülke refahlarını artıracağı mantalitesi çerçevesinde, Türkiye'nin bu aday ülkeler karşısındaki rekabet gücü, 'Karşılaştırmalı İhracat Performansı' açısından değerlendirilmek istenmektedir. Fakat literatürde ülkelerin uluslararası rekabet güçlerini ölçmek amacıyla kullanılabilecek tek ve kesin bir yöntem bulunmamaktadır (WziatekKubiak, 2003). Buna karşılık Klasik dış ticaret teorilerinin temel kuramı olan 'Karşılaştırmalı Üstünlükler' çerçevesinde geliştirilmiş ve yıllar içerisinde şekillenmiş bazı rekabet gücü ölçüm indeksleri ile ülkelerin sektörel ve ülke bazlı rekabet 
avantajları ortaya koyulmaya çalışılmaktadır. Çalışmada kullanılacak olan ve Donges vd. (1982) tarafından geliştirilmiş 'Karşılaştırmalı İhracat Performansı İndeksi' - 'CEP' (Comparative Export Performance Index) de bunlardan bir tanesidir. CEP indeksi; bir ülkenin rakipleri karşısındaki rekabet avantajını ihracata konu olan her bir mal/mal grubu için ölçmekte kullanılan bir indekstir (Gacaner Atış, 2014). Çalışmanın temel amacı Türkiye'nin diğer AB-28 aday ülkeleri karşısındaki rekabet avantajını gözlemlemek olduğu için; bir ihracat performansı ölçümlemesi yapılması uygun görülmüştür. Ayrıca literatürde Türkiye'nin diğer AB-28 aday ülkeleri karşısında ihracat performanslarını karşılaştırmalı olarak gösteren herhangi bir çalışmaya rastlanmamış ve bu çalışmada CEP indeksinin kullanılmasının bu boşluğu bir nebze de olsa doldurabileceği düşünülmüştür.

Bu çerçevede çalışmanın ilk bölümü AB28 aday ve potansiyel aday ülkelerinin adaylık süreçlerinin kısa bir geçmişini aktarmak amacıyla düzenlenmiştir. İkinci bölümde bu ülkelerin gerek dünya, gerekse $\mathrm{AB}$ içerisindeki diş ticaret potansiyelleri 2006-2016 yıl aralığı baz alınarak açıklanmıştır. Üçüncü bölüm uygulamada kullanılacak olan Donges ve arkadaşlarının (1982) geliştirdiği Karşılaştırmalı İhracat Performansı İndeksi'ni (CEP) açıklayan ve literatürdeki konuyla ilgili çalışmaları değerlendiren bir bölüm olmuştur. Son bölüm ise çalışmanın uygulama kısmıdır ki, bu noktada aday ülkelerin Türkiye karşısındaki "İmalat" ve "Tarım" gibi temel sektörlerin yanında, "Gıda", "Tekstil", "Demir Çelik" ve "Kimyasallar" sektörü gibi özellikli sektörlerdeki karşılaştırmalı ihracat performanslarının ölçüldüğü ve bulguların değerlendirildiği kısımdır.

\section{AB28 ADAY VE POTANSIYYL ADAY ÜLKELERININ ADAYLIK} SÜREÇLERI

Çalışmanın gerçekleştirildiği tarih itibariyle, AB'nin genişleme politikası çerçevesinde aday olarak değerlendirilen toplam 7 ülke bulunmaktadır. Bu ülkelerden Türkiye, Sirbistan, Karadağ, Arnavutluk ve Makedonya aday ülke konumunda yer alırken; Bosna-Hersek ve Kosova potansiyel aday ülke statüsüne sahip ülkeler olarak değerlendirilmektedir (İKV, 2017).

AB'ye aday ülke statüsüyle katılan Türkiye'nin AB ile geçmişi diğer aday ülkelerin hikayelerinden oldukça farklıdır. Türkiye bu yolculuğa 1959 yılında AET (Avrupa Ekonomi Topluluğu) ile imzaladığı Ankara Anlaşması ile çıkmış, 1995 yılında Toplulukla arasında Gümrük Birliği statüsünde kısmi çerçeveli bir ekonomik entegrasyon kurulmasının ardından, 1999 yılında Helsinki Zirvesi ile Birliğe "aday ülke" statüsüyle kabulünü sağlayabilmiştir. Türkiye'nin adaylığı bu nedenle Birliğin geçmişindeki en uzun adaylık süreci olarak dikkat çekmektedir. Bu süreç tam 40 y1llık bir geçmişi kapsamaktadır. 
Makedonya üyelik için AB'ye 2004 y1lı başlarında başvurmuş ve 2005 yılı sonunda onay almıştır. Bu hızlı onayla Hırvatistan'ın ardından adaylık statüsü kazanan ilk Batı Balkan ülkesi unvanına da sahip olmuştur (T.C. AB Bakanlığı, 2017). Fakat ne yazık ki ülke, Yunanistan'ın engellemeleriyle yüzleşmek zorunda kalarak, AB ile katılım müzakerelerinin başlamasında sıkıntılar yaşamaktadır. Yunanistan, kendi topraklarında bulunan aynı isimli bölge adının varlığını öne sürerek, Makedonya'nın anayasal ismini kullanmasının kendi ülkesindeki bu bölge için de bir hak doğurabileceği iddiası ile bu duruma olumsuz yaklaşmaktadır. Ayrıca Makedonya'da 2015 yılında başlayan siyasi kriz sürecin sürekli ertelenmesi sonucunu doğurmaktadır (İKV, 2017).

Karadă 2006 yılında Sırbistan'dan ayrılıp bağımsızlığını ilan etmesinin ardından, 2008 y1lı sonunda AB'ye üyelik başvurusunu gerçekleştirmiştir. $\mathrm{Bu}$ başvurudan tam iki yıl sonra ülke resmen aday ülke olarak ilan edilmiş ve 2012 Haziran'ında $\mathrm{AB}$ - Karadağ arasındaki katılım müzakerelerine başlanmıştır (T.C. AB Bakanlı̆̆ı, 2017). Karadağ'ın 2015'in Aralık ayında NATO üyeliğine davet edilmesi AB'nin 2016 ülke ilerleme raporlarına olumlu bir şekilde intikal ederken, ülkenin yolsuzluklarla mücadele konusunda önemli adımlar atması gereği ayrıca vurgulanmıştır (İKV, 2017).

Sırbistan, Federal Yugoslavya'nın dağılması aşamasında yaşanan ve modern insanlık tarihi için büyük bir ayıp olarak kabul edilen savaş ve katliamların en büyük suçlusu olarak değerlendirilmesine rağmen; tüm bu yaşananların sorumlusu olarak kabul edilenlerin tutuklanıp Lahey'e sevki neticesinde $\mathrm{AB}$ kapılarının aralanmasını sağlayabilmiştir (IKV, 2017). 2009 Aralık ayındaki AB üyelik başvurusu, 2012 Mart ayında kabul edilmiş ve 2014 yılı itibariyle $\mathrm{AB}$ ile tam üyelik müzakerelerine başlama avantajını elde edebilmiştir. Fakat Sırbistan Müzakere Çerçeve Belgesi'nin, Sırbistan'ın başta Kosava olmak üzere, diğer devletlerle ilişkilerini normalleştirmesi gereğine oldukça fazla vurgu yaptığı gözlenmektedir (T.C. AB Bakanlığı, 2017).

Arnavutluk, Haziran 2003 tarihinde geçekleştirilen Selanik Zirvesi'nde diğer Batı Balkan ülkeleriyle birlikte $\mathrm{AB}$ 'ye potansiyel aday ülke olarak kayda geçmiştir. Bunun üzerine 2009 yllında da AB'ye resmi üyelik başvurusunu gerçekleştirmiştir. Komisyon'un 2012 yılında Arnavutluk'a yargı ve kamu yönetimi reformu ve parlamento ile ilgili kural ve prosedürlerin revizyonu konularındaki tavsiyeleri neticesinde, 2014 Haziran'ında resmen aday ülke statüsüne kavuşmuştur (T.C. AB Bakanlı̆ğ, 2017). Fakat Komisyon; aday ülke olarak kabulün hemen katılım müzakerelerine başlanacağı anlamına gelmemesi gerektiği konusunun altını önemle çizmiştir (İKV, 2017). Sonuç olarak Arnavutluk, 2016 yılı temmuz ayı itibariyle katılım müzakerelerine başlanabilmesi için olur elde edebilmiştir. 
KUŞAT | Turkey's Competitiveness Against EU28 Candidate Countries According to the...

Bosna-Hersek de 2013 Haziran ayı itibariyle potansiyel aday ülke statüsüsüne kabul edilen Batı Balkan ülkelerinden bir tanesidir. 2008 yılı itibariyle Birlik'le İstikrar ve Ortaklık Anlaşması'nı imzalamış olmasına rağmen, bu anlaşmanın yürürlüğe girmesi Mart 2015'de gerçekleşmiştir (T.C. AB Bakanlığı, 2017). Bosna-Hersek'in Şubat 2016'da yaptığı tam üyelik başvurusu Eylül 2016'da kabul edilmiş olmakla birlikte, ülkeyle henüz müzakere sürecine geçilmemiştir (T.C. Dış İşleri Bakanlığı, 2017).

Kosova ise $\mathrm{AB}$ adaylık süreci en son başlayan Batı Balkan ülkesidir. Kosova'nın $\mathrm{AB}$ üyelik sürecinde önünde bulunan önemli bir sorun vardır ki, beş $\mathrm{AB}$ üyesi devlet tarafından (Romanya, Slovakya, İspanya, Yunanistan ve Güney Kıbrıs Rum Yönetimi) tanınmıyor olmasıdır (İKV, 2017). Kosova, Ekim 2013 tarihi itibariyle AB ile İstikrar ve İşbirliği Anlaşması müzakerelerine başlamış, bu müzakereler Temmuz 2014'de olumlu sonuçlanmış ve Ekim 2015'de İstikrar ve İşbirliği Anlaşması imzalanmıştır. Fakat 2015 yılı İlerleme Raporu'nda Kosova'nın henüz AB'ye uyum konusunda pek çok alanda erken bir aşamada bulunduğu belirtilmektedir (İKV, 2017).

\section{AB28 VE AB ADAY / POTANSIYYL ADAY ÜLKELERININ DIŞ TİCARET GÖRÜNÜMLERİ}

$\mathrm{Bu}$ bölümde $\mathrm{AB} 28$ ve aday/potansiyel aday ülkelerin önce dünya ticareti içerisindeki dış ticaret değerlerine, sonrasında ise aday ve potansiyel aday ülkelerin $\mathrm{AB}$ ile ticaretlerinin değer ve paylarına göz atılmaktadır. Fakat AB-28'e potansiyel aday ülke statüsündeki Kosova'nın dış ticaret verilerine ulaşılamadığı için bu tablolarda yer almamaktadır.

2.1. AB28 ve AB Aday/Potansiyel Aday Ülkelerinin Tüm Dünya İle Dış Ticaretlerinin Görünümü

Tablo 1, 2006-2016 yılları arasında AB28 ve aday ülkelerinin tüm dünya ile gerçekleştirilen ihracat değerlerini göstermek için düzenlenmiştir.

Tablo 1. AB28 ve AB Aday Ülkeleri Toplam İhracat Değerleri (2006-2016) (Milyon \$)

\begin{tabular}{ccccccccc} 
Yıllar & Dünya & AB28 & Türkiye & Sirbistan & Karadağ & Arnavutluk & Makedonya & BosnaHersek \\
$\mathbf{2 0 0 6}$ & 12131000 & 4606065 & 85535,0 & 6428,0 & 556,5 & 798,0 & 2401,0 & 3323,0 \\
$\mathbf{2 0 0 7}$ & 14023000 & 5366010 & 107271,8 & 8824,7 & 626,3 & 1077,6 & 3398,3 & 4152,0 \\
$\mathbf{2 0 0 8}$ & 16160000 & 5954870 & 132027,2 & 10972,1 & 616,6 & 1354,8 & 3990,6 & 5021,1 \\
$\mathbf{2 0 0 9}$ & 12555000 & 4613535 & 102142,6 & 8345,1 & 387,5 & 1090,6 & 2708,5 & 3953,9 \\
$\mathbf{2 0 1 0}$ & 15301000 & 5183905 & 113883,2 & 9794,5 & 436,6 & 1544,6 & 3351,4 & 4803,1 \\
$\mathbf{2 0 1 1}$ & 18338000 & 6092185 & 134906,9 & 11779,5 & 627,5 & 1951,0 & 4478,3 & 5850,1 \\
$\mathbf{2 0 1 2}$ & 18496000 & 5808580 & 152461,7 & 11229,0 & 468,8 & 1968,0 & 4015,4 & 5161,8 \\
$\mathbf{2 0 1 3}$ & 18953000 & 6076950 & 151802,6 & 14614,4 & 498,4 & 2331,5 & 4298,8 & 5687,3 \\
$\mathbf{2 0 1 4}$ & 19001000 & 6158385 & 157610,2 & 14845,2 & 440,9 & 2430,6 & 4964,1 & 5890,7 \\
$\mathbf{2 0 1 5}$ & 16488000 & 5389370 & 143838,9 & 13378,9 & 351,8 & 1929,6 & 4530,1 & 5099,2 \\
$\mathbf{2 0 1 6}$ & 15985000 & 5379330 & 142557,4 & 14851,8 & 360,5 & 1962,1 & 4787,2 & 5326,7 \\
\hline Kaynak:
\end{tabular}

Hacettepe University Journal of Economics and Administrative Sciences |

Vol 37, Issue 1, 2019

116 
2006 yılı itibariyle 12.131 .000 milyon \$ olan dünya ihracatının, 2016 yılında yaklaşık \%32 oranında artarak 15.985 .000 milyon \$'a yükseldiği gözlenmektedir. AB ülkeleri ise 2006 yllında bu ihracat değerinin yaklaşık \%38'ini gerçekleştirirken, 2016 yılında yaklaşık \%34'ünü gerçekleştirmeye başlamışlardır. Dünya toplam ihracatı içerisindeki payları oransal olarak azalmasına rağmen, $\mathrm{AB}$ ülkeleri yine de dünyanın lider ihracatçı ülke/ülke grubunu oluşturmaktadır.

$\mathrm{AB}$ aday ülkeleri arasında dünya ihracatı içerisinde en fazla ağırlığa sahip olan ülke ise Türkiye'dir. Türkiye'yi sırasıyla Sırbistan, Bosna Hersek, Makedonya, Arnavutluk ve Karadağ takip etmektedir. Tablo 1 ayrıca Karadağ'ın ihracatında yıllar itibariyle meydana gelen aşınmayı da göstermektedir.

Tablo 2, 2006-2016 y1lları arasında AB28 ve aday ülkelerinin tüm dünya ile gerçekleştirdikleri ithalat değerlerini göstermek için düzenlenmiştir.

\section{Tablo 2. AB28 ve AB Aday Ülkeleri Toplam İthalat Değerleri} (2006-2016) (Milyon \$)

\begin{tabular}{llrlrrrrr} 
Yıllar & Dünya & \multicolumn{1}{c}{ AB28 } & Türkiye & Sirbistan & Karadă & Arnavutluk & Makedonya & Bosna Hersek \\
$\mathbf{2 0 0 6}$ & 12461000 & 4870290 & 139576,0 & 13172,3 & 1841,5 & 3058,0 & 3762,7 & 7345,0 \\
$\mathbf{2 0 0 7}$ & 14330000 & 565516 & 170062,7 & 19164,0 & 2867,3 & 4187,5 & 5280,6 & 9720,1 \\
$\mathbf{2 0 0 8}$ & 16572000 & 6358375 & 201963,6 & 24331,0 & 3731,2 & 5250,6 & 6882,7 & 12188,6 \\
$\mathbf{2 0 0 9}$ & 12782000 & 4809190 & 140928,4 & 16047,4 & 2313,1 & 4550,0 & 5072,8 & 8773,3 \\
$\mathbf{2 0 1 0}$ & 15511000 & 5421065 & 185544,3 & 16734,5 & 2181,9 & 4405,9 & 5474,5 & 9223,0 \\
$\mathbf{2 0 1 1}$ & 18503000 & 6330060 & 240841,7 & 19861,9 & 2544,0 & 5395,7 & 7027,2 & 11050,6 \\
$\mathbf{2 0 1 2}$ & 18705000 & 5950945 & 236545,1 & 18924,9 & 2336,4 & 4482,3 & 6522,4 & 10019,1 \\
$\mathbf{2 0 1 3}$ & 19016000 & 6011965 & 251661,3 & 20542,5 & 2354,3 & 4901,7 & 6619,6 & 10294,9 \\
$\mathbf{2 0 1 4}$ & 19095000 & 6145655 & 242177,0 & 20608,6 & 2369,3 & 5229,8 & 7301,4 & 10990,4 \\
$\mathbf{2 0 1 5}$ & 16734000 & 5325300 & 207234,4 & 18211,2 & 2039,4 & 4320,4 & 6426,8 & 8994,0 \\
$\mathbf{2 0 1 6}$ & 16229000 & 5342585 & 198618,2 & 19237,3 & 2285,6 & 4669,2 & 6757,5 & 9129,6
\end{tabular}

2006 yılı itibariyle 12.461 .000 milyon \$ olan dünya ithalatının, 2016 yılında yaklaşı \%30 oranında artarak 16.229.000 milyon \$’a yükseldiği gözlenmektedir. AB ülkeleri ise 2006 yılında bu ithalat değerinin yaklaşı \%39'unu gerçekleştirirken, 2016 yılında $\% 6$ 'lık bir azalışla yaklaşık \%33'ünü gerçekleştirmeye başlamışlardır. Dünya toplam ithalatı içerisindeki payları oransal olarak azalmasına rağmen, $\mathrm{AB}$ ülkeleri yine de dünyanın lider ithalatçı ülke grubunu oluşturmaktadır.

$\mathrm{AB}$ aday ülkeleri arasında dünya ithalatı içerisinde en fazla ağırlığa sahip olan ülke ise, ihracatta da olduğu gibi, Türkiye'dir. Türkiye'yi sırasıyla Sirbistan, Bosna Hersek, Makedonya, Arnavutluk ve Karadağ takip etmektedir. Tablo 1 tüm aday ülkelerin ithalatlarının 2006-2016 yıl aralığında arttığını da göstermektedir. 
2.2. AB28 ve AB Aday/Potansiyel Aday Ülkelerinin AB ile Dış Ticaretlerinin Görünümü

Tablo 3 AB28 aday ülkelerinin AB ile gerçekleştirdikleri ihracat değerlerini göstermek için düzenlenmiştir.

Tablo 3. Aday Ülkelerin AB28 Ülkeleriyle Gerçekleştirdikleri Toplam İhracat Değerleri* (2006-2016) (Milyon \$)

$\begin{array}{lrrrrrc}\text { Yıllar } & \text { Türkiye } & \text { Sirbistan } & \text { Karadă } & \text { Arnavutluk } & \text { Makedonya } & \text { Bosna Hersek } \\ \mathbf{2 0 0 6} & 49035,00 & 3867,00 & 379,70 & 704,40 & 1593,80 & 2687.00 \\ \mathbf{2 0 0 7} & 61686,30 & 5265,70 & 441,70 & 896,60 & 2347,40 & 3140,80 \\ \mathbf{2 0 0 8} & 64779,50 & 6387,40 & 390,70 & 1081,60 & 2589,70 & 3625,60 \\ \mathbf{2 0 0 9} & 47985,00 & 4755,90 & 200,00 & 922,80 & 1665,30 & 2808,60 \\ \mathbf{2 0 1 0} & 53958,80 & 5921,90 & 249,60 & 1088,20 & 2195,20 & 3338,20 \\ \mathbf{2 0 1 1} & 63614,80 & 7259,10 & 376,00 & 1419,40 & 2844,30 & 4112,20 \\ \mathbf{2 0 1 2} & 60442,50 & 6894,10 & 240,20 & 1488,70 & 2621,10 & 3750,40 \\ \mathbf{2 0 1 3} & 64157,20 & 9165,40 & 202,70 & 1788,90 & 3122,90 & 4182,40 \\ \mathbf{2 0 1 4} & 68567,50 & 9593,00 & 157,70 & 1882,40 & 3801,50 & 4248,40 \\ \mathbf{2 0 1 5} & 64008,50 & 8778,40 & 126,00 & 1452,50 & 3465,40 & 3652,20 \\ \mathbf{2 0 1 6} & 68375,40 & 9825,80 & 129,50 & 1528,90 & 3825,00 & 3797,80\end{array}$

Kaynak: WTO, 2017.

*Tablodaki değerler aynı zamanda AB28'in aday ülkelere olan ihracat değerlerini göstermektedir.

Tablo 3'deki veriler, AB ülkelerine gerçekleştirilen ihracat açısından Türkiye'nin lider konumunu oldukça net bir şekilde ortaya koymaktadır. 2006 yılından 2015 yılına kadar Türkiye'den sonra AB'ye gerçekleştirilen ihracat sıralaması Sırbistan, Bosna Hersek, Makedonya Arnavutluk ve Karadağ şeklinde kendisini gösterirken, 2016 yılı itibariyle bu sıralamada Bosna Hersek'in Makedonya'nın gerisine düştüğü gözlenmektedir.

Tablo 4 AB28 aday ülkelerinin AB ile gerçekleştirdikleri ithalat değerlerini göstermek için düzenlenmiştir. 


\section{Tablo 4. Aday Ülkelerin AB28 Ülkeleriyle Gerçekleștirdikleri Toplam İthalat Değerleri* (2006-2016) (Milyon \$)}

$\begin{array}{llrrrrc}\text { Yıllar } & \text { Türkiye } & \text { Sirbistan } & \text { Karadağ } & \text { Arnavutluk } & \text { Makedonya } & \text { Bosna Hersek } \\ \mathbf{2 0 0 6} & 59501,30 & 6374,70 & 953,00 & 2045,30 & 2071,10 & 5302,40 \\ \mathbf{2 0 0 7} & 68749,60 & 10745,90 & 1418,10 & 2557,80 & 2697,80 & 6365,30 \\ \mathbf{2 0 0 8} & 74568,80 & 12742,30 & 1756,70 & 3241,30 & 3431,90 & 7929,10 \\ \mathbf{2 0 0 9} & 56659,10 & 9536,90 & 981,00 & 2997,50 & 2750,00 & 5358,60 \\ \mathbf{2 0 1 0} & 72449,30 & 9799,50 & 929,20 & 3060,50 & 3025,90 & 5627,00 \\ \mathbf{2 0 1 1} & 91520,40 & 11513,80 & 1032,80 & 3521,00 & 3956,80 & 6597,80 \\ \mathbf{2 0 1 2} & 87733,10 & 11532,80 & 1038,90 & 3086,30 & 3928,00 & 6146,90 \\ \mathbf{2 0 1 3} & 92524,60 & 12727,50 & 1035,70 & 3133,40 & 4151,50 & 6180,30 \\ \mathbf{2 0 1 4} & 88783,70 & 12999,20 & 1083,30 & 3195,80 & 4633,10 & 6472,30 \\ \mathbf{2 0 1 5} & 78668,80 & 11362,00 & 845,90 & 2665,80 & 3974,10 & 5470,40 \\ \mathbf{2 0 1 6} & 77495,40 & 12127,90 & 1087,70 & 2950,60 & 4189,00 & 5610,20\end{array}$

Kaynak: WTO, 2017.

*Tablodaki değerler aynı zamanda AB28'in aday ülkelere olan ihracat değerlerini göstermektedir.

Tablo 4'ü incelemek kaydıyla, AB'den gerçekleştirilen ithalat açısından Türkiye'nin diğer $\mathrm{AB}$ aday ülkeleri karşısındaki lider konumunun devam ettiğini söylemek mümkündür. Aday ülkelerin $\mathrm{AB}$ 'den gerçekleştirdikleri ithalat miktarları ne kadar değişirse değişsin, kendi içlerinde ithalat sıralamalarının her yıl sabit kaldığ gözlenmektedir. Tüm aday ülkeler Türkiye'yi açık ara farkla takip ederken, Türkiye'den sonra sirasıyla en fazla ithalatı Sirbistan, Bosna Hersek, Makedonya, Arnavutluk ve Karadağ' 1 gerçekleştirdiği de gözlenmektedir.

$\mathrm{AB}$ aday ülkelerinin $\mathrm{AB} 28$ ile gerçekleştirdikleri diş ticaretin toplam ticaretleri içerisindeki yerini ortaya koymak daha doğru bir değerlendirmede bulunmamızı sağlayabilir. Çünkü ülkelerin toplam dış ticaret potansiyelleri, özellikle Türkiye karşısında, oldukça farklı değere sahiptir. Bu nedenle Tablo 5 düzenlenmiştir.

Tablo 5. AB Aday Ülkelerinin Toplam İhracatları İçinde AB İhracatlarının Payı (\%) (2006-2016)

\begin{tabular}{|c|c|c|c|c|c|c|c|c|c|c|c|c|}
\hline \multirow[b]{2}{*}{ Yillar } & \multicolumn{2}{|c|}{ Türkiye } & \multicolumn{2}{|c|}{ Surbistan } & \multicolumn{2}{|c|}{ Karadă̆ } & \multicolumn{2}{|c|}{ Arnavutluk } & \multicolumn{2}{|c|}{ Makedonya } & \multicolumn{2}{|c|}{ Bosna Hersek } \\
\hline & İhr. & İth. & İhr. & İth. & İhr. & İth. & İhr. & İth. & İhr. & İth. & İhr. & İth \\
\hline 2006 & 57 & 43 & 60 & 48 & 68 & 52 & 88 & 67 & 66 & 72 & 81 & 72 \\
\hline 2007 & 58 & 40 & 60 & 56 & 71 & 49 & 83 & 61 & 69 & 65 & 76 & 65 \\
\hline 2008 & 49 & 37 & 58 & 52 & 63 & 47 & 80 & 62 & 65 & 40 & 72 & 65 \\
\hline 2009 & 47 & 40 & 57 & 59 & 52 & 42 & 85 & 66 & 61 & 60 & 71 & 61 \\
\hline 2010 & 47 & 39 & 60 & 59 & 57 & 43 & 70 & 69 & 66 & 72 & 70 & 61 \\
\hline 2011 & 47 & 38 & 62 & 58 & 60 & 41 & 73 & 65 & 64 & 56 & 70 & 60 \\
\hline 2012 & 40 & 37 & 61 & 61 & 51 & 44 & 76 & 69 & 65 & 64 & 73 & 61 \\
\hline 2013 & 42 & 37 & 63 & 62 & 41 & 44 & 77 & 64 & 73 & 70 & 74 & 60 \\
\hline 2014 & 44 & 37 & 65 & 63 & 36 & 46 & 77 & 61 & 77 & 54 & 72 & 59 \\
\hline 2015 & 45 & 38 & 66 & 62 & 36 & 41 & 75 & 62 & 76 & 65 & 72 & 61 \\
\hline 2016 & 48 & 39 & 66 & 63 & 36 & 48 & 78 & 63 & 80 & 62 & 71 & 61 \\
\hline
\end{tabular}

Kaynak: WTO, 2017. 
KUŞAT | Turkey's Competitiveness Against EU28 Candidate Countries According to the...

2006-2016 yılları arasında, Sırbistan ve Makedonya hariç tüm aday ülkelerin AB ile olan ihracat oranlarının 2006'daki değerlerinin altına düştüğü gözlenmektedir. Sirbistan 2006'daki \%60'lık AB ihracat oranın1 2016'da \%66'ya ve Makedonya ise $\% 66$ 'lık ihracat oranını \%80'e yükseltmiştir. Türkiye'nin \%57'lik ihracat payının $\% 48$ 'e, Karadağ' 1 \%68'den \%36'ya, Arnavutluk'un \%88'den \%78'e ve Bosna'nın $\% 81$ 'den $\% 71$ 'e gerilediği dikkat çekmektedir. $\mathrm{AB}$ aday ülkelerinin $\mathrm{AB}$ 'ye olan ihracatlarındaki bu değişime rağmen, toplam ihracatı içerisinde AB'yle en fazla ticari ilişki kuran ülkenin Makedonya olduğu da görülmektedir. Türkiye'nin 2006 yılından itibaren AB'ye gerçekleştirdiği ihracatın oransal olarak azalması düşündürücüdür.

İncelenen y1l periyodunda AB28'den gerçekleştirdiği ithalatın toplam ithalatı içerisindeki payı artan tek ülke Sırbistan olmuştur (2006'da \%48 - 2016'da \%63). Diğer aday ülkelerin AB28 ithalatlarının ise oransal olarak azaldığı dikkat çekmektedir. Tablo 5'de dikkat çeken bir diğer sonuç ise, AB28'den gerçekleştirdiği ithalat miktarı toplam ithalat değeri içerisinde en az paya sahip olan ülkenin, incelenen her y1l aralığı için Türkiye olmasıdır (2006'da \%43, 2016'da \%39).

\section{IHHRACATTA REKABET GÜCÜ ÖLÇÜMÜ}

Uluslararası ticaretin en önemli varsayımlarının başında "Karşılaştırmalı Üstünlükler/Avantajlar” gelir. Karşılaştırmalı üstünlüklerin kaynağı her ne olursa olsun, uluslararası ticaretin en üst seviyeye taşınmasını sağlamada kullanılabilecek en iyi strateji olduğu da kabul edilmektedir (Lin vd., 1999). Bu nedenle karşılaştırmalı üstünlükler ülkelerin rekabet gücünün ortaya konması açısından oldukça önemli unsurlardır. Yine bu nedenledir ki ülkelerin karşılaştırmalı üstünlüğe sahip oldukları sektörleri tespit etmek önem arz eder. İşte tam bu noktada işin içerisine karşılaştırmalı üstünlüklerin hesaplanmasını sağlayan indekslerin girdiğini görmekteyiz.

\subsection{Karşılaştırmalı İhracat Performansı İndeksi (CEP)}

İhracat verilerinden yararlanmak kaydıyla bir ülkenin rekabet gücünü ölçmeye yönelik ilk çalışma Liesner (1958) tarafından yapılmış olup, indeks değerinin hesaplamasında ülkenin bir üründeki toplam ihracatının o ürünü ihraç eden diğer ülkelerin toplam ihracatına oranı kullanılmıştır (Utkulu, Seymen, 2004:7-8).

Rekabet gücünün ölçülmesinde kullanılan ve zaman içerisinde geliştirilen en ünlü indeks ise Balassa'ya ait olup, Açıklanmış Karşılaştırmalı Üstünlükler (Revealed Comparative Advantage - RCA) adıyla anılır (Bilas, Bošnjak; 2015). Balassa bu indeksi Liesner'in çalışmasından alarak geliştirmiş, bu indeks zaman içerisinde pek çok araştırmacıya 1şık tutmuş ve yeri geldikçe değiştirilerek yeni indekslerin teşekkülüne aracılık etmiştir. 
Donges $v d$. (1982) tarafindan geliştirilen Karşılaştırmalı İhracat Performansı indeksi'de (Comparative Export Performance-CEP), Balassa indeksinin geliştirilmesiyle hayat bulan ve bir ülkenin rakip ülkeler karşısındaki sektörel rekabet gücünü ölçmek amaciyla kullanılan bir indekstir. Donges $v d$.'ne göre (1982) ithalatı da içine alan RCA indeksleri, tarife ve kotalar gibi ithalat üzerindeki politik kararları da içinde barındırdığından, yanlış değerlendirmelere firsat verebilecektir. Buna karşın ihracat üzerindeki teşvikler, ithalat üzerindeki politik uygulamalardan daha az öneme sahip olduğundan, rekabet ölçümlemesinde ihracat verilerinden yararlanılması daha doğru olacaktır (Donges $v d .$, 1982: 83).

Donges $v d$. (1982) Balassa indeksinden yararlanarak ülkeler arasındaki rekabet gücünü hesaplamak amacıyla geliştirdikleri Karşılaştırmalı İhracat Performansı indeksi (CEP) aşağıdaki gibi formüle edilebilir:

$$
\mathrm{CEP}_{\mathrm{irj}}=\left(\mathrm{X}_{\mathrm{ij}} / \mathrm{X}_{\mathrm{rj}}\right) /\left(\mathrm{X}_{\mathrm{it}} / \mathrm{X}_{\mathrm{rt}}\right)
$$

$\mathrm{Bu}$ eşitlikte; $\mathrm{CEP}_{\mathrm{irj}}$ i ülkesinin rakip ülke karşısında $\mathrm{j}$ mal grubundaki ihracat uzmanlık indeksi katsayısını; (Xij) i ülkesinin $\mathrm{j}$ mal grubundaki ihracatını; $\left(\mathrm{X}_{\mathrm{it}}\right) \mathrm{i}$ ülkesinin toplam ihracatını; $\left(X_{\mathrm{r}}\right)$ rakip ülkenin $\mathrm{j}$ mal grubundaki ihracatını; $\left(\mathrm{X}_{\mathrm{rt}}\right)$ rakip ülkenin toplam ihracatını göstermektedir.

$\mathrm{Bu}$ indeks hesaplama yöntemi sonucunda bir ülkenin farklı mal grupları için hesaplanan CEP indeks değeri 1'den büyükse, ülke o mal grubundaki ihracatında avantaja sahipken, 1'den küçük bulunması durumunda dezavantaja sahip olduğu kabul edilir (Kösekahyaoğlu, 2012). Hinloopen, Marrewijk (2001) ise; indeks değeri 0 ile 1 arasında ise karşılaştırmalı üstünlük yoktur, 1 ile 2 arasında ise zayıf bir karşılaştırmalı üstünlük vardır, 3 ile 4 arasında ise orta derecede karşılaşıırmalı üstünlük vardır, 4'ün üzerinde ise güçlü bir karşılaştırmalı üstünlük vardır, şeklinde bir derecelendirme yapılmasının mümkün olduğundan bahsetmektedir.

Tüm bu açıklamalardan da anlaşılacağı üzere; Donges ve arkadaşlarının geliştirdiği Karşılaştırmalı İhracat Performans İndeksi CEP, aslında Balassa'nın kullandığı İhracat Uzmanlık İndeksi ESI'dan çok da farklı bir indeks değildir. Hesaplamalarda kullanılan değerlerde bir değişiklik yer almazken pay ve paydada bu değerlerin kullanıldığı yerlerde bir değişiklik söz konusudur. Hatta yorumlanması bile neredeyse birebir aynıdır.

\subsection{Literatür Taraması}

Ülkelerin rakip ülkeler karşısındaki rekabet gücünü ölçmede kullanılan ve çıkış noktası Balassa'ya dayanan indekslerin, pek çok çalışmada pek çok araştırmacı tarafından farklı ülkeler üzerinde kullanıldı̆̆ 1 gözlenmektedir. CEP indeksi de bu 
KUŞAT | Turkey's Competitiveness Against EU28 Candidate Countries According to the...

anlamda önem arz eden ve rekabet gücü ölçümlemesinde literatüre katkı sağlayan bir indeks olarak dikkat çeker.

CEP indeksinin temeli Balassa'nın (1965) Açıklanmış Karşılaştırmalı Üstünlükler İndeksi -RCA- ya dayanmakla birlikte; RCA ile sadece bir ülkenin ihraç ettiği mal/mal grupları açısından rekabet gücü ölçümü yapılması mümkün olabilmektedir (Gacaner Atış, 2014). Oysa CEP indeksi ile rakip ülkelerin rekabet güçleri karşılaştırmalı bir şekilde hesaplanabilmekte ve bu sayede ülkelerin ihraç mal/mal gruplarındaki ihracat performansları karşılaştırmalı bir şekilde yansıtılabilmektedir. Literatür incelendiğinde, Balassa'nın orijinal endeksinin diğer rekabet gücü ölçümünde kullanılan endekslere göre daha az sınırlama getirmesi (De Benedictis, Tamberi, 2002) nedeniyle çalışmalarda daha yoğun kullanıldığ gözlenmektedir. Buna rağmen CEP indeksi kullanılarak rakip ülkelerin ihracat performanslarını karşılaştırmalı şekilde ortaya koyan çalışma sayısı daha kısıtlı kalmaktadır.

Oysaki CEP endeksi, ülkenin kısmi ihracat payları üzerinden rekabet gücünü ölçümlerken, incelenen ülkelerin ve mal gruplarının toplam ihracat değerlerini hesaplamanın dışında tutarak, hesaplamada iki kez kullanımı engellemekte ve bu sayede olası sapmaları ortadan kaldırabilmektedir.

Kısıtlı sayıda olsa da; literatürde CEP indeksinden yararlanmak kaydıyla, farklı ülkeler ve farklı mal/mal grupları için yapılmış çalışmalara rastlanmaktadır. $\mathrm{Bu}$ çalışmalar genel olarak yakın bir geçmişe sahip olup, bazılarına Tablo 6'da yer verilmiştir.

Tablo 6. CEP Endeksine Göre Yapılmış Bazı Yerli ve Yabancı Çalışmalar

\begin{tabular}{|l|l|l|l|}
\hline Araştırmacı & Yıl & Karşılaştırma yapılan ülkeler & İncelenen sektör \\
\hline Saraçoğlu ve Köse & 2000 & $\begin{array}{l}\text { İtalya, Fransa, Belçika, ABD, } \\
\text { Tayland, Almanya, İspanya, } \\
\text { Kanada, Hollanda, Belçika, } \\
\text { Lüksemburg, İngiltere, } \\
\text { Danimarka, Çin ve Japonya }\end{array}$ & $\begin{array}{l}\text { Makarna, Bisküvi ve } \\
\text { Buğday Unu }\end{array}$ \\
\hline Akgüngör $v d$. & 2002 & $\begin{array}{l}\text { Türkiye, Yunanistan, Portekiz, } \\
\text { İspanya }\end{array}$ & $\begin{array}{l}\text { Domates, Üzüm ve } \\
\text { Narenciye İşleme }\end{array}$ \\
\hline $\begin{array}{l}\text { Kösekahyaoğlu ve } \\
\text { Özdamar }\end{array}$ & 2005 & $\begin{array}{l}\text { Türkiye, Çek, Macaristan, } \\
\text { Polonya, Estonya }\end{array}$ & Tüm Mal Grupları \\
\hline Türkekul $v d$. & 2010 & $\begin{array}{l}\text { Türkiye, Tunus, İspanya, } \\
\text { Yunanistan, Suriye }\end{array}$ & Zeytinyağ1 \\
\hline Gacaner Atış & 2014 & $\begin{array}{l}\text { Türkiye, AB-27, ABD, Orta } \\
\text { Doğu-Kuzey Afrika }\end{array}$ & $\begin{array}{l}\text { Tekstil ve } \\
\text { Konfeksiyon }\end{array}$ \\
\hline Şahin & 2016 & Türkiye, BRIC & İmalat \\
\hline Alidou $v d$. & 2017 & Benin, Nijerya, Burkina Faso & Tarım \\
\hline
\end{tabular}




\section{4. ÇALIŞMANIN YÖNTEM, BULGU VE SONUÇLARI}

\section{1. Çalışmanın Yöntemi}

Gerçekleştirilen çalışma ile içerisinde Türkiye'nin de yer aldığ1 AB28 aday ülkelerinin, Türkiye karşısındaki ihracat rekabet güçleri 2006-2016 yıl aralığı içerisinde ölçülmeye çalışılmaktadır. Bu ölçümlemede, Balassa'nın İhracat Uzmanlaşma İndeksi ESI'dan yola çıkılarak 1982 yılında Donges $v d$. tarafindan geliştirilen CEP kullanılmıştır. Giriş bölümünde de belirtildiği üzere CEP'in kullanılma gerekçelerinden bir tanesi, bu indeksin bir ülkenin rakipleri karşısındaki rekabet avantajını ihraç edilen her bir mal grubu için ayrı ayrı ölçebilme kabiliyetidir. Diğer gerekçe ise, literatürde Türkiye'nin AB-28 aday ülkeleri karşısındaki ihracat performansını ölçümleyen bir çalışmanın henüz yapılmamış olmasının yarattığı boşluktur.

Bu kapsam dahilinde mal ihracatında yer alan belli başlı sektörler dikkate alınarak hesaplamalar gerçekleştirilmiştir. Çalışmada kullanılan tüm veriler Dünya Ticaret Örgütü (WTO)'nun internet sitesinden çekilmiştir ${ }^{3}$.

WTO mal ihracatını 33 alt sektörde değerlendirmektedir. Bu 33 sektör WTO'nun internet sitesinde yer aldığı haliyle Tablo 7'de verilmiştir.

Tablo 7. WTO’ya Göre Mal Ticareti Sektörel Sinıflaması

\begin{tabular}{|c|c|c|}
\hline Tarım Ürünleri & Otomotiv Ürünleri & Kimyasallar \\
\hline Giyim & Ofis Ekipmanları & Elektrikli Makinalar \\
\hline Balık & Gıda & Yakıtlar \\
\hline Entegre Devreler & Demir-Çelik & Makine ve Ulaşım Ekipmanları \\
\hline İmalat & Çeşitli İmalat & Elektriksiz Makinalar \\
\hline Demirsiz Metaller & Ofis ve Haberleşme & Cevherler ve Diğer Mineraller \\
& Ekipmanları & Diğer Makineler \\
\hline Diğer Kimyasallar & Diğer Gıda Ürünleri & Diğer Ulaşım Ekipmanları \\
\hline Diğer İmalatlar & Diğer Yarı Mamuller Makineler \\
\hline Kişisel ve Ev & Eczacılık Ürünleri & Gü \\
Eşyaları & Bilimsel ve Denetleyici Ürünler & Telekomünikasyon Ekipmanları \\
\hline Hammadde & Toplam Yakıt ve Maden & Taşıma Ekipmanları \\
\hline Tekstil & Ürünleri & \\
&
\end{tabular}

Tablo 7'de belirtilen bu alt sektörlerden imalat, tarım, gıda, tekstil, demir çelik ve kimyasallar sektörü örneklemimize alınmıştır. 33 sektörden sadece 6 tanesinin analiz çerçevesinde değerlendirilmesinin bir sebebi, bu seçilen sektörlerin Türkiye için ekonomik önem derecelerinin diğer sektörlere göre yüksek olmasıdır. Bir diğer sebebi 
ise, Türkiye'nin rakipleri karşısındaki bütün sektörel ihracat performanslarını görmeye çalışırken, özellikli sektörlerin ihracat performanslarını tam olarak yansıtamama çekincesidir.

Her bir sektör için 2006-2016 yıl periyodunda Türkiye'nin; Surbistan, Karadağ, Arnavutluk, Bosna Hersek ve Makedonya karşısındaki sektörel ihracat performansı hesaplanmıştır. Çalışmada yıl aralığının 2006-2016 olarak belirlenmesinin ve 2006 yılından itibaren değerlendirmenin yapılmasının sebebi ise; Karadağ'ın 2006 yılında bağımsızlığını ilan etmesidir. Dolayısıyla Karadağ'ın 2006 yılından önceki dış ticaret verilerine ulaşılamamaktadır.

\section{2. Çalıșmanın Bulgu ve Sonuçları}

Bu başlık altında Donges ve Arkadaşlarının Karşılaştırmalı İhracat Performansı İndeksi'ne göre Türkiye'nin diğer aday ülkeler karşısındaki ihracat performansı imalat, tarım, gıda, tekstil, demir çelik ve kimyasallar sektörü için ayrı ayrı hesaplanarak ${ }^{4}$ yorumlanmaktadir.

Bu hesaplamada kullanılan ana formül Donges ve arkadaşlarının orijinal indeks formülüne sadık kalınmak kaydıyla aşağıdaki şekilde kullanılmıştır:

CEP1 = Türkiye'nin X Sektörü İhracatı / Rakip Ülkenin X Sektörü İhracatı

Türkiye'nin Toplam Ihracatı / Rakip Ulkenin Toplam Ihracatı

CEP1 Türkiye'deki X sektörünün rakip ülke karşısındaki ihracat performansını dünya ihracatı genelinde ölçümlemektedir.

CEP2 = Türkiye'nin X Sektörü İhracatı / Rakip Ülkenin X Sektörü İhracatı Türkiye'nin AB'ye Top. Ihr. / Rakip Ulkenin AB'ye Top. Ihr.

CEP2 Türkiye'deki X sektörünün rakip ülke karşısındaki ihracat performansını AB ihracatı genelinde ölçümlemektedir.

\subsubsection{Türkiye'nin İmalat Sektörü Karşılaştırmalı İhracat Performansı}

Türkiye'nin diğer AB28 aday ülkeler karşısındaki imalat sektörü karşılaştırmalı ihracat performansı ölçüm sonuçları Tablo 8'de sunulmuştur. 
Tablo 8. Türkiye'nin AB28 Aday Ülkeleri Karşısındaki İmalat Sektörü CEP Değerleri (2006-2016)

$\begin{array}{ccccccccccc}\begin{array}{c}\text { Ülkeler } \\ \text { Yıllar }\end{array} & \begin{array}{c}\text { Sirbistan } \\ \text { CEP1 }\end{array} & \text { CEP2 } & \begin{array}{c}\text { Karadağ } \\ \text { CEP1 }\end{array} & \text { CEP2 } & \text { CEP1 } & \text { CEP2 } & \text { CEP1 } & \text { CEP2 } & \text { CEP1 } & \text { CEP 2 } \\ & & & & & & & & & & \\ \mathbf{2 0 0 6} & 1,28 & 1,34 & 3,25 & 3,86 & 1,10 & 1,69 & 1,16 & 1,35 & 1,42 & 2,00 \\ \mathbf{2 0 0 7} & 1,23 & 1,28 & 3,31 & 4,06 & 1,15 & 1,67 & 1,08 & 1,29 & 1,34 & 1,76 \\ \mathbf{2 0 0 8} & 1,16 & 1,38 & 2,24 & 2,89 & 1,12 & 1,83 & 1,01 & 1,34 & 1,27 & 1,87 \\ \mathbf{2 0 0 9} & 1,23 & 1,50 & 2,42 & 2,66 & 1,09 & 1,97 & 1,51 & 1,98 & 1,29 & 1,95 \\ \mathbf{2 0 1 0} & 1,31 & 1,67 & 3,51 & 4,24 & 1,25 & 1,86 & 1,14 & 1,58 & 1,42 & 2,08 \\ \mathbf{2 0 1 1} & 1,30 & 1,70 & 4,40 & 5,59 & 1,29 & 1,99 & 1,09 & 1,47 & 1,39 & 2,07 \\ \mathbf{2 0 1 2} & 1,16 & 1,80 & 3,63 & 4,70 & 1,27 & 2,43 & 0,99 & 1,62 & 1,18 & 2,17 \\ \mathbf{2 0 1 3} & 1,13 & 1,68 & 4,39 & 4,22 & 1,46 & 2,64 & 1,01 & 1,73 & 1,27 & 2,20 \\ \mathbf{2 0 1 4} & 1,13 & 1,68 & 4,63 & 3,80 & 1,47 & 2,61 & 0,96 & 1,69 & 1,20 & 1,99 \\ \mathbf{2 0 1 5} & 1,10 & 1,63 & 2,99 & 2,40 & 1,42 & 2,39 & 0,92 & 1,58 & 1,14 & 1,84 \\ \mathbf{2 0 1 6} & 1,11 & 1,53 & 2,98 & 2,23 & 1,14 & 1,84 & 0,91 & 1,52 & 1,14 & 1,69\end{array}$

CEP 1 ölçümlemesine göre; Türkiye'nin imalat sektöründe 2011 yılına kadar diğer aday ülkelerin hepsine karşı rekabet üstünlüğüne sahip olduğu gözlenmektedir. 2012 yılından itibaren Makedonya karşısındaki rekabet üstünlüğünü yitirmeye başladığı, ama diğer ülkeler karşısında hala rekabetçiliğini koruduğu da anlaşılmaktadır. Bunun yanı sıra incelenen yıl aralığı itibariyle Türkiye'nin İmalat sektörü ihracatındaki rekabet avantajında, Arnavutluk hariç, genel anlamda kayıplar olduğu da gözlenmektedir.

CEP 2 ölçümlemesine göre; Türkiye'nin karşılaştırmalı ihracat performansı, tüm aday ülkeler karşısında 1 'in üzerinde bulunmuştur. Bu açıdan Türkiye'nin, AB ile gerçekleştirdiği imalat sektörü ihracatında diğer aday ülkelere karşı avantajlı konumda olduğunu söyleyebiliriz. Fakat buna karşın incelenen yıl aralığında Türkiye'nin Karadağ ve Bosna Hersek karşısında imalat sektörü rekabet avantajının düşme eğilimine girdiği de gözlenmektedir.

\subsubsection{Türkiye'nin Tarım Sektörü Karşılaştırmalı İhracat Performansı}

Türkiye'nin diğer AB28 aday ülkeler karşısındaki tarım sektörü karşılaştırmalı ihracat performansı ölçüm sonuçları Tablo 9'da sunulmuştur. 
Tablo 9. Türkiye’nin AB28 Aday Ülkeleri Karşısındaki Tarım Sektörü CEP

\begin{tabular}{|c|c|c|c|c|c|c|c|c|c|c|}
\hline \multirow{3}{*}{$\begin{array}{l}\text { Ülkeler } \\
\text { Yıllar }\end{array}$} & \multicolumn{8}{|c|}{ Değerleri (2006-2016) } & \multirow{2}{*}{\multicolumn{2}{|c|}{ Bosna Hersek }} \\
\hline & \multicolumn{2}{|c|}{ Surbistan } & \multicolumn{2}{|c|}{ Karadağ } & \multicolumn{2}{|c|}{ Arnavutluk } & \multicolumn{2}{|c|}{ Makedonya } & & \\
\hline & CEP1 & CEP2 & CEP1 & CEP2 & CEP1 & CEP2 & CEP1 & CEP2 & CEP1 & CEP2 \\
\hline 2006 & 0,46 & 0,48 & 0,74 & 0,88 & 1,01 & 1,55 & 0,58 & 0,67 & 0,71 & 1,01 \\
\hline 2007 & 0,43 & 0,44 & 0,69 & 0,85 & 1,02 & 1,47 & 0,62 & 0,75 & 0,65 & 0,86 \\
\hline 2008 & 0,44 & 0,53 & 0,62 & 0,81 & 1,11 & 1,80 & 0,66 & 0,87 & 0,66 & 0,98 \\
\hline 2009 & 0,44 & 0,53 & 0,53 & 0,58 & 1,24 & 2,24 & 0,58 & 0,75 & 0,77 & 1,17 \\
\hline 2010 & 0,45 & 0,58 & 0,53 & 0,65 & 1,56 & 2,32 & 0,65 & 0,89 & 0,82 & 1,20 \\
\hline 2011 & 0,49 & 0,64 & 0,65 & 0,83 & 1,64 & 2,53 & 0,75 & 1,02 & 0,85 & 1,27 \\
\hline 2012 & 0,41 & 0,63 & 0,47 & 0,60 & 1,45 & 2,76 & 0,66 & 1,09 & 0,74 & 1,35 \\
\hline 2013 & 0,57 & 0,85 & 0,54 & 0,52 & 1,67 & 3,03 & 0,73 & 1,25 & 0,80 & 1,38 \\
\hline 2014 & 0,54 & 0,80 & 0,32 & 0,27 & 1,52 & 2,71 & 0,89 & 1,57 & 0,83 & 1,37 \\
\hline 2015 & 0,53 & 0,79 & 0,43 & 0,35 & 1,19 & 2,01 & 0,99 & 1,70 & 0,77 & 1,23 \\
\hline 2016 & 0,52 & 0,72 & 0,46 & 0,34 & 1,09 & 1,78 & 0,94 & 1,57 & 0,71 & 1,06 \\
\hline
\end{tabular}

CEP 1 değerleri Türkiye’nin tarım sektöründe aday ülkeler karşısındaki ihracat performansının beklendiği kadar iyi olmadığını göstermektedir. Nihayetinde Türkiye'nin sadece Arnavutluk karşısında rekabet gücü sağlayabildiği, diğer aday ülkelerin karşısında ise incelenen tüm yıllar için hep geride kalan bir performansa sahip olduğu gözlenmektedir. Türkiye'nin incelenen dönem genelinde tarım sektöründe Sırbistan ve Makedonya karşısında bir miktar rekabet avantajı yakalama çabası içerisine girdiği, fakat Karadağ'ın Türkiye karşısındaki sektörel rekabet avantajlarının artma eğilimi gösterdiği de görülmektedir.

CEP 2 değerleri ise Türk tarım sektörünün $\mathrm{AB}$ içerisindeki ihracat yapısında aday ülkeler karşısında daha fazla avantajlı olduğunu göstermektedir. En azından Türkiye AB karşısında; Arnavutluk'un yanı sıra Makedonya ve Bosna Hersek'e karşı da bir rekabet avantajı yakalamıştır.

\subsubsection{Türkiye'nin Gıda Sektörü Karşılaştırmalı İhracat Performansı}

Türkiye'nin diğer AB28 aday ülkeler karşısındaki g1da sektörü karşılaştırmalı ihracat performansı ölçüm sonuçları Tablo 10’da sunulmuştur.

CEP 1 Türkiye'nin küresel ihracat içerisindeki gıda sektörü ihracat performansında da aday ülkeler karşısında çok başarılı olamadığını göstermektedir. Türkiye bu sektörde sadece Arnavutluk karşısında bir rekabet avantajı yakalayabilmiştir.

AB ihracatı içerisindeki ihracat performansı ölçüm sonuçlarını gösteren CEP 2'ye göreyse, Türkiye'nin Arnavutluk'un yanı sıra Makedonya ve Bosna Hersek karşısında da bir rekabet avantajına sahip olduğu gözlenmektedir. 
Tablo 10. Türkiye'nin AB28 Aday Ülkeleri Karşısındaki Gıda Sektörü CEP Değerleri (2006-2016)

\begin{tabular}{cccccccccccc}
$\begin{array}{c}\text { Ülkeler } \\
\text { Yıllar }\end{array}$ & \multicolumn{2}{c}{ Sirbistan } & \multicolumn{2}{c}{ Karadağ } & \multicolumn{2}{c}{ Arnavutluk } & \multicolumn{2}{c}{ Makedonya } & \multicolumn{2}{c}{ Bosna Hersek } \\
& CEP1 & CEP2 & CEP1 & CEP2 & CEP1 & CEP2 & CEP1 & CEP2 & CEP1 & CEP2 \\
$\mathbf{2 0 0 6}$ & 0,49 & 0,51 & 1,11 & 1,32 & 1,64 & 2,53 & 0,58 & 0,67 & 0,68 & 0,96 \\
$\mathbf{2 0 0 7}$ & 0,45 & 0,47 & 1,03 & 1,26 & 1,58 & 2,29 & 0,62 & 0,75 & 0,62 & 0,81 \\
$\mathbf{2 0 0 8}$ & 0,47 & 0,55 & 0,82 & 1,07 & 2,02 & 3,29 & 0,66 & 0,88 & 0,63 & 0,93 \\
$\mathbf{2 0 0 9}$ & 0,45 & 0,55 & 0,71 & 0,78 & 1,83 & 3,30 & 0,57 & 0,75 & 0,75 & 1,13 \\
$\mathbf{2 0 1 0}$ & 0,47 & 0,60 & 0,74 & 0,90 & 2,30 & 3,43 & 0,64 & 0,89 & 0,79 & 1,16 \\
$\mathbf{2 0 1 1}$ & 0,52 & 0,67 & 0,91 & 1,16 & 2,54 & 3,91 & 0,75 & 1,01 & 0,81 & 1,21 \\
$\mathbf{2 0 1 2}$ & 0,42 & 0,65 & 0,64 & 0,82 & 2,13 & 4,07 & 0,66 & 1,09 & 0,71 & 1,30 \\
$\mathbf{2 0 1 3}$ & 0,59 & 0,88 & 0,74 & 0,72 & 2,43 & 4,41 & 0,73 & 1,26 & 0,76 & 1,33 \\
$\mathbf{2 0 1 4}$ & 0,56 & 0,83 & 0,41 & 0,34 & 2,25 & 4,01 & 0,89 & 1,57 & 0,80 & 1,32 \\
$\mathbf{2 0 1 5}$ & 0,55 & 0,81 & 0,68 & 0,54 & 1,74 & 2,94 & 1,00 & 1,72 & 0,74 & 1,19 \\
$\mathbf{2 0 1 6}$ & 0,53 & 0,74 & 0,73 & 0,54 & 1,36 & 2,21 & 0,95 & 1,58 & 0,68 & 1,02
\end{tabular}

İncelenen dönem itibariyle Türkiye'nin gıda sektörü ihracatındaki rekabet avantajının Sırbistan, Makedonya ve Bosna Hersek karşısında genel olarak yükselme, Karadağ ve Arnavutluk karşısında ise düşme eğilimi gösterdiği de görülmektedir.

\subsubsection{Türkiye'nin Tekstil Sektörü Karşılaştırmalı İhracat Performansı}

Türkiye'nin diğer AB28 aday ülkeler karşısındaki tekstil sektörü karşılaş̧ırmalı ihracat performansı ölçüm sonuçları Tablo 11'de sunulmuştur.

Türkiye, tekstil sektörü için hesaplanan CEP 1 ve CEP 2 değerlerine göre, tüm aday ülkeler karşısında yüksek oranlı bir ihracat performansına sahip olduğunu kanıtlamaktadır. Özellikle de Karadağ karşısında elde etmiş olduğu yüksek performans dikkat çekicidir. Fakat Türkiye'nin Karadağ karşısındaki sektörel ihracat performansının yüksekliğine rağmen; incelenen periyotta Karadağ tekstil sektörünün Türk tekstil sektörü karşısındaki ihracat performansında bir artış meydana geldiği de dikkat çekmektedir. 
Tablo 11. Türkiye’nin AB28 Aday Ülkeleri Karşısındaki Tekstil Sektörü CEP Değerleri (2006-2016)

\begin{tabular}{lcccccccccc} 
Ülkeler & \multicolumn{2}{c}{ Sirbistan } & \multicolumn{2}{c}{ Karadag } & \multicolumn{2}{c}{ Arnavutluk } & \multicolumn{2}{c}{ Makedonya } & \multicolumn{2}{c}{ Bosna Hersek } \\
Yillar & CEP1 & CEP2 & CEP1 & CEP2 & CEP1 & CEP2 & CEP1 & CEP2 & CEP1 & CEP2 \\
& & & & & & & & & & \\
$\mathbf{2 0 0 6}$ & 7,76 & 8,14 & 123,37 & 146,83 & 20,81 & 32,05 & 4,70 & 5,44 & 14,73 & 20,78 \\
$\mathbf{2 0 0 7}$ & 7,90 & 8,20 & 174,03 & 213,43 & 16,63 & 24,07 & 5,72 & 6,87 & 14,48 & 19,05 \\
$\mathbf{2 0 0 8}$ & 7,67 & 9,10 & 109,74 & 141,72 & 11,91 & 19,37 & 5,97 & 7,89 & 7,27 & 10,69 \\
$\mathbf{2 0 0 9}$ & 7,37 & 8,94 & 293,02 & 321,93 & 11,45 & 20,63 & 4,50 & 5,89 & 6,06 & 9,17 \\
$\mathbf{2 0 1 0}$ & 8,14 & 10,39 & 114,55 & 138,21 & 12,53 & 18,64 & 4,67 & 6,45 & 7,83 & 11,48 \\
$\mathbf{2 0 1 1}$ & 7,51 & 9,81 & 250,53 & 318,36 & 16,57 & 25,57 & 5,95 & 8,01 & 9,18 & 13,68 \\
$\mathbf{2 0 1 2}$ & 6,17 & 9,55 & 84,98 & 109,83 & 18,53 & 35,36 & 4,84 & 7,98 & 8,17 & 14,98 \\
$\mathbf{2 0 1 3}$ & 7,16 & 10,63 & 199,44 & 191,92 & 18,12 & 32,89 & 4,46 & 7,66 & 9,31 & 16,20 \\
$\mathbf{2 0 1 4}$ & 6,07 & 9,02 & 116,71 & 95,95 & 18,04 & 32,11 & 5,03 & 8,86 & 8,52 & 14,13 \\
$\mathbf{2 0 1 5}$ & 5,93 & 8,75 & 133,93 & 107,80 & 66,78 & 112,97 & 5,16 & 8,88 & 6,40 & 10,30 \\
$\mathbf{2 0 1 6}$ & 5,81 & 8,00 & 92,00 & 68,89 & 10,58 & 17,18 & 4,72 & 7,87 & 6,77 & 10,07
\end{tabular}

İncelenen yıl aralığı kapsamında genel olarak Türkiye'nin tekstil sektöründeki rekabet avantajının azalmakta olduğu gözlenmektedir. Türk tekstil sektörü karşısında göreceli olarak en güçlü sayılabilecek aday ülke Makedonya'dır. Fakat bu ülkenin yıllar itibariyle Türk tekstil sektörü karşısındaki ihracat performansında düşme eğilimi tespit edilmektedir.

\subsubsection{Türkiye’nin Demir Çelik Sektörü Karşılaştırmalı İhracat Performansı}

Türkiye'nin diğer AB28 aday ülkeler karşısındaki demir çelik sektörü karşılaştırmalı ihracat performansı ölçüm sonuçları Tablo 12'de sunulmuştur.

Tablo 12. Türkiye'nin AB28 Aday Ülkeleri Karşısındaki Demir Çelik Sektörü CEP Değerleri (2006-2016)

\begin{tabular}{|c|c|c|c|c|c|c|c|c|c|c|}
\hline \multirow{2}{*}{$\begin{array}{l}\text { Ülkeler } \\
\text { Yıllar }\end{array}$} & \multicolumn{2}{|c|}{ Surbistan } & \multicolumn{2}{|c|}{ Karadağ } & \multicolumn{2}{|c|}{ Arnavutluk } & \multicolumn{2}{|c|}{ Makedonya } & \multicolumn{2}{|c|}{ Bosna Hersek } \\
\hline & CEP1 & CEP2 & CEP1 & CEP2 & CEP1 & CEP2 & CEP1 & CEP2 & CEP1 & CEP2 \\
\hline 2006 & 0,62 & 0,65 & 0,62 & 0,74 & 2,96 & 0,74 & 0,30 & 0,35 & 2,27 & 1,65 \\
\hline 2007 & 0,72 & 0,75 & 0,59 & 0,72 & 2,96 & 0,72 & 0,24 & 0,29 & 2,67 & 1,66 \\
\hline 2008 & 0,97 & 1,15 & 0,55 & 0,72 & 1,50 & 0,72 & 0,33 & 0,44 & 3,75 & 2,53 \\
\hline 2009 & 1,14 & 1,39 & 0,75 & 0,82 & 2,23 & 0,82 & 1,42 & 1,86 & 4,77 & 3,42 \\
\hline 2010 & 0,92 & 1,18 & 1,53 & 1,85 & 0,88 & 1,85 & 0,39 & 0,53 & 3,47 & 2,49 \\
\hline 2011 & 1,13 & 1,48 & 1,57 & 1,99 & 0,85 & 1,99 & 0,42 & 0,57 & 3,27 & 2,42 \\
\hline 2012 & 2,60 & 4,03 & 1,92 & 2,48 & 0,88 & 2,48 & 0,41 & 0,68 & 2,86 & 2,41 \\
\hline 2013 & 2,73 & 4,05 & 2,34 & 2,25 & 0,93 & 2,25 & 0,41 & 0,70 & 3,62 & 2,45 \\
\hline 2014 & 2,07 & 3,07 & 5,02 & 4,13 & 0,84 & 4,13 & 0,46 & 0,82 & 3,12 & 2,05 \\
\hline 2015 & 1,50 & 2,21 & 0,82 & 0,66 & 0,93 & 0,66 & 0,43 & 0,75 & 3,10 & 1,90 \\
\hline 2016 & 1,53 & 2,11 & 1,16 & 0,87 & 0,90 & 0,87 & 0,53 & 0,89 & 3,63 & 1,93 \\
\hline
\end{tabular}


Bir ülke ekonomisi için önem arz eden bir diğer sektör de demir çelik sektörüdür. Türkiye'nin dünya genelindeki demir çelik sektörü ihracat performansının (CEP 1) Sırbistan, Karadağ ve Bosna karşısında yüksek olmasına rağmen; Arnavutluk ve Makedonya karşısında zayıf kaldığı gözlenmektedir. Türkiye'nin $A B$ içerisindeki ihracat performansında (CEP 2) ise Sırbistan ve Bosna Hersek karşısında iyi bir avantaj yakalarken, Karadağ karşısındaki avantajını kaybettiği dikkat çekmektedir.

Türkiye'nin incelenen y1llar itibariyle Sirbistan, Karadağ ve Bosna Hersek karşısındaki demir çelik sektörü ihracat performansını yükselterek bu aday ülkeler karşısında bir rekabet avantajı yakaladığı, fakat Arnavutluk karşısındaki rekabet avantajını zamanla yitirdiği tespit edilmiştir.

\subsubsection{Türkiye'nin Kimyasallar Sektörü Karşılaştırmalı İhracat Performansı}

Türkiye'nin diğer AB28 aday ülkeler karşısındaki kimyasallar sektörü karşılaştırmalı ihracat performansı ölçüm sonuçları Tablo 13'de sunulmuştur.

Tablo 13. Türkiye'nin AB28 Aday Ülkeleri Karşısındaki Kimyasallar Sektörü CEP Değerleri (2006-2016)

\begin{tabular}{lcccccccccr}
$\begin{array}{l}\text { Ülkeler } \\
\text { Yıllar }\end{array}$ & \multicolumn{2}{c}{ Sirbistan } & \multicolumn{2}{c}{ Karadag } & \multicolumn{2}{c}{ Arnavutluk } & \multicolumn{2}{c}{ Makedonya } & \multicolumn{2}{c}{ Bosna Hersek } \\
& CEP1 & CEP2 & CEP1 & CEP2 & CEP1 & CEP2 & CEP1 & CEP2 & CEP1 & CEP2 \\
$\mathbf{2 0 0 6}$ & 0,41 & 0,44 & 1,78 & 2,12 & 12,87 & 19,82 & 1,00 & 1,16 & 1,08 & 1,53 \\
$\mathbf{2 0 0 7}$ & 0,39 & 0,41 & 1,91 & 2,34 & 10,49 & 15,18 & 1,05 & 1,26 & 1,00 & 1,32 \\
$\mathbf{2 0 0 8}$ & 0,42 & 0,50 & 1,66 & 2,15 & 9,37 & 15,25 & 1,38 & 1,82 & 0,88 & 1,29 \\
$\mathbf{2 0 0 9}$ & 0,60 & 0,73 & 1,11 & 1,22 & 7,27 & 13,10 & 1,06 & 1,39 & 0,92 & 1,38 \\
$\mathbf{2 0 1 0}$ & 0,60 & 0,77 & 1,37 & 1,65 & 11,03 & 16,40 & 0,47 & 0,65 & 1,06 & 1,55 \\
$\mathbf{2 0 1 1}$ & 0,62 & 0,81 & 1,97 & 2,50 & 5,49 & 8,47 & 0,32 & 0,42 & 0,97 & 1,44 \\
$\mathbf{2 0 1 2}$ & 0,65 & 1,00 & 1,40 & 1,81 & 8,52 & 16,26 & 0,31 & 0,51 & 0,87 & 1,60 \\
$\mathbf{2 0 1 3}$ & 2,51 & 3,72 & 2,28 & 2,20 & 7,51 & 13,63 & 0,29 & 0,50 & 0,98 & 1,70 \\
$\mathbf{2 0 1 4}$ & 0,72 & 1,08 & 1,52 & 1,25 & 7,76 & 13,81 & 0,27 & 0,48 & 0,89 & 1,48 \\
$\mathbf{2 0 1 5}$ & 0,68 & 1,00 & 1,41 & 1,14 & 10,27 & 17,37 & 0,25 & 0,44 & 0,82 & 1,31 \\
$\mathbf{2 0 1 6}$ & 0,62 & 0,86 & 1,02 & 0,76 & 4,89 & 7,94 & 0,23 & 0,38 & 0,70 & 1,04
\end{tabular}

Türkiye'nin kimyasallar sektöründeki dünya geneli ihracat performansı değerleme sonuçlarına göre (CEP 1) aday ülkelerden Karadağ ve Arnavutluk karşısında yüksek bir ihracat performansına sahip olduğunu söylemek mümkündür. Avrupa genelinde ise (CEP 2) Arnavutluk ve Bosna Hersek karşısında yüksek bir ihracat performansına sahip olduğu ve bu ülkelere karşı bir rekabet avantajı elde ettiği gözlenmektedir.

Karşılaştırmalı ihracat performansı değerlendirme sonuçlarına göre Türkiye'nin incelenen yıl aralı̆̆ı çerçevesinde kimyasallar sektöründe, Sırbistan hariç, genel olarak bir rekabet gücü azalışı ile yüzleştiği tespit edilmiştir. 


\section{SONUC}

Bu çalışma Türkiye gibi AB'ye üyelik sürecini tamamlamaya çalışan ülkelerin, Türkiye karşısındaki karşılaştırmalı ihracat performanslarını ölçmek amacıyla gerçekleştirilmiştir. Çalışmanın kapsamına Türkiye hariç 5 aday ülke (Sırbistan, Karadağ, Arnavutluk, Makedonya ve Bosna Hersek) ve 6 sektör (İmalat, Tarım, Gıda, Tekstil, Demir Çelik ve Kimyasallar) dahil edilmiştir. Çalışmada Donges $v d$. tarafından 1982 yılında geliştirilmiş olan CEP İndeksi kullanılarak hem dünya geneli hem de AB28 toplam ihracat değerleri baz alınmış ve Türkiye'nin diğer aday ülkeler karşısındaki performansı hesaplanmışıır. Elde edilen sonuçlar hem Türkiye, hem de diğer aday ülkeler adına her bir sektör için farklı performansların ortaya çıktığını göstermektedir.

Çalışma kapsamında elde edilen sonuçları değerlendirmeden önce, tekstil, gıda ve tarım sektörlerinin Türk dış ticaretini sürükleyen üç güçlü sektör olduğunu hatırlamak gerekir. Fakat çalışma bulguları bu beklentiyi tam olarak desteklememektedir.

Şöyle ki; çalışma bulguları Türkiye'nin rakip ülkeler karşısında tekstil sektöründe sahip olduğu yüksek rekabet avantajını ortaya koymaktadır. Fakat sonuçlar tekstil sektöründe elde edilen bu avantajın incelenen yıllar boyunca aşındığını da göstermektedir. Türk gıda sektöründe ise tüm beklentilerin boşa çıtı̆ğı ve bu sektörde Türkiye'nin rakipleri karşısında bir rekabet avantajı yakalayamadığı gözlenmektedir. Fakat incelenen yıl aralığı boyunca Türk gıda sektöründe rekabet adına olumlu hareketlenmelerin başladığı da çalışma sonuçlarından anlaşılmaktadır. Türk tarım sektörü ise, bir tarım ülkesi olarak nitelendirilen bir ülkeye yakışmayan bir performans sergilemektedir. Türk tarım sektörü Arnavutluk, Makedonya ve Bosna Hersek karşısında kısmi oranda bir avantaj yakalamasına rağmen; Sırbistan ve Karadağ tarım sektörleri karşısında rekabet gücüne sahip değildir.

Ayrıca Türkiye'nin tüm incelenen sektörler çerçevesinde sadece Bosna Hersek karşısında yüksek bir rekabet avantajı yakaladığı da aşikardır. Başka bir deyişle Bosna Hersek adı geçen sektörlerde rekabet gücü en düşük olan ülkedir.

Çalışma sonuçları imalat sektöründe Makedonya'nın, tarım ve gıda sektörlerinde Karadağ ve Surbistan'ın, demir çelik sektöründe Makedonya ve Arnavutluk'un, kimyasallar sektöründe Makedonya ve Sırbistan'ın Türkiye karşısında önemli bir rekabet avantajı yakaladıklarına da dikkat çekmektedir.

Genel bir sonuç vermek gerekirse; Türkiye, $\mathrm{AB}$ aday ülkeleri karşısında tekstil sektöründeki ihracat performansı ile dikkat çekmektedir. Bu anlamda tekstil sektörü Türkiye'nin incelenen ülke ve sektörler açısından karşılaştırmalı üstünlüğe sahip olduğu tek sektör olmaktadır. Bu açıdan Türkiye'nin tekstil sektöründe yakaladığı bu avantajı 
sürdürülebilir kılması bir zorunluluktur. Türkiye'de tekstil ihracatında öne çıkan firmaların KOBİ ağırlıklı olması, bu firmalara yönelik ihracat teşviklerinin yeniden gözden geçirilmesini gerektirmektedir.

Türkiye gıda sektöründeki zayıf ama pozitif yönlü rekabet avantajını da acilen güçlendirmek zorundadır. Aynı durum Türk tarım sektörü için de geçerlidir. Bir tarım ülkesi olup da, tarım sektöründe rekabet avantajını rakiplerine devretmek zorunda kalmak anlaşılabilir bir durum değildir. Bu ülkenin bir tarım reformuna ihtiyacı olduğu aşikardır. Bu düzenleme ile mevcut tarım arazilerinin daha verimli hale getirilmesi sağlanarak; hem tarımsal üretimin hem de istihdam artışının yaratılması mümkün olabilir.

Türkiye'nin Makedonya karşısında imalat, demir çelik ve kimyasallar sektöründeki rekabet dezavantajının gittikçe arttığı düşünüldüğünde, bu sektörler konusunda da radikal bir takım güçlendirici kararların alınması gereği önem arz etmektedir. Aslında sektörün adına bakılmaksızın, herhangi bir sektörde karşılaştırmalı üstünlük adına bir kayıp yaşanıyorsa; bu sektörü yeniden canlandırmak her hükümetin, her özel ve kamu ticari kurum kuruluşun birinci görevi olmalıdır. Bu konuda devlet teşviklerinin yanı sıra, ticaret ve sanayi odalarının, üniversitelerin, sivil toplum kuruluşlarının maddi ve manevi desteklerine ihtiyaç vardır.

Diğer açıdan, Türkiye AB28'e tam üye olarak entegrasyonunu gerçekleştirmek istiyorsa, bu aday ülkelerden daha üstün ve vazgeçilmez olduğunu bu birliğe ispat etmek zorundadır. Bunun tek yolu da güçlü bir üretim ve yüksek bir ihracat performansından geçmektedir.

Çivi ve Demiray Erol'un (2008)'de belirttiği gibi; dünyanın her yerinde uygulanabilecek homojen özellikte bir rekabet gücü artırıcı model yoktur. Fakat yine de bir ülkenin rekabet gücünün artırılması münferit politikalarla değil, ancak ve ancak bütünleşik ve sürdürülebilir politikalarla sağlanabilir. Bu politikalar da kamu-özel işbirliği içerisinde hazırlanan akılcı politikalar olmalarının yanında, uygulanabilirliği yüksek olan politikalar da olmak zorundadır. Ayrıca bu politikalar tüketimi değil, üretimi teşvik eden; kısa vadeli değil, uzun vadeli sonuçlar ortaya koyan politikalar olmalıdır.

\section{NOTLAR}

${ }^{1} 2016$ yılı AB28 içi ihracat değeri 3.449.292 milyon \$'dır.

${ }^{2} 2016$ yılı AB28 içi ithalat değeri 3.449.292 milyon \$'dır.

${ }^{3}$ www.wto.org adresine girildikten sonra sirasiyla; Home - Resources - Statistics - Statistics On Merchandise Trade - International Trade and Market Access Data seçilerek istenilen verilere ulaşılmıştır.

${ }^{4}$ Tüm CEP hesaplamalarında https://www.wto.org adresinden elde edilen veriler kullanılmıştır. 
KUŞAT | Turkey's Competitiveness Against EU28 Candidate Countries According to the...

\section{KAYNAKÇA}

Akgüngör, S., R.F. Barbaros, N. Kumral (2002), "Competitiveness of the Turkish Fruit and Vegetable Processing Industry in the European Union Market”, Russian \& East European Finance and Trade, 38(3), 34-53.

Alidou, M., R.F. Ceylan, E. Ilbasmıs (2017), "Trade and Revealed Comparative Advantage Measures: A Case of Main Export Crops of Benin Republic", Kastamonu Üniversitesi Íktisadi ve İdari Bilimler Fakültesi Dergisi, 18(1), 382-397, ICEBSS 2017 Özel Say1.

Balassa, B. (1965), "Trade Liberalization and 'Revealed', Comparative Advantage", The Manchaster School of Economic and Social Studies, 33(2), 99-123.

Bilas, V., M. Bošnjak (2015), Revealed Comparative Advantage and Merchandise Exports: The Case of Merchandise Trade Between Croatia and the Rest of the European Union Member Countries, Ekon. Misao Praksa Dbk. God XXIV., Br. 1. 29-47.

Çivi, E., E. Demiray Erol (2008), "Ulusal Rekabet Gücünü Arttırma Yolları: Literatür Araştırması”, Yönetim ve Ekonomi Dergisi, 15(1), 99-114.

De Benedictis, L., M. Tamberi (2002), “A Note on the Balassa Index of Revealed Comparative Advantage", Universita' Politecnica delle Marche (I), Dipartimento di Scienze Economiche e Sociali, Working Papers 158.

Donges, J.B., C. Krieger-Boden, R.J. Langhammer, K-W. Schatz, C.S. Thoroe (1982), "The Second Enlargement of The European Community: Adjustment Requirements and Challenges for Policy Reform", Kieler Studien, No:171. Kiel.

Gacaner Atış A. (2014), “Türkiye'nin Tekstil ve Konfeksiyon Sektörünün Karşıllaştırmalı Rekabet Analizi”, Ege Akademik Bakış, 14(2), 315-334.

Hinloopen, J., C.V. Marrewijk (2001), "On the Empirical Distribution of the Balassa Index", Review of World Economics, 137(1), 1-35.

İKV, http://www.ikv.org.tr/ikv.asp?id=282, E.T. 10.11.2017.

Kösekahyaoğlu, L. (2012), Dış Ticaret ve Rekabet Gücü 1923-2011, Ankara: Alter.

Kösekahyaoğlu, L., G. Özdamar (2005), “Türkiye, Çek Cumhuriyeti, Macaristan, Polonya ve Estonya'nın Sektörel Rekabet Gücü ve Dış Ticaret Yapısı Üzerine Karşılaştırmalı Bir Analiz”, Sosyoekonomi, Temmuz-Aralık, 2, 73-102.

Liesner, H.H. (1958), “The European Common Market and British Industry”,.Economic Journal, 68: 302-316.

Lin, J.Y., F. Cai, Z. Li (1996), The China Miracle: Development Strategy and Economic Reform, Hong Kong: Chinese University Press.

Saraçoğlu, B., N. Köse (2000), "Bazı Gıda Sanayilerinin Uluslararası Rekabet Gücü: Makarna, Bisküvi ve Un Sanayi”, Proje Raporu, 2000-2, Mayıs 2000, Ankara.

Şahin, D. (2016), “İmalat Sanayinde Rekabet Gücünün Ölçümü: Türkiye ve BRIC Ülkeleri Örneği”, Ege Akademik Bakış, 16(4), 709-718.

T.C. AB Bakanlığ 1 , http://www.ab.gov.tr/index.php?p=267\&l=1, E.T. 10.11.2017.

T.C. AB Bakanlığ1, http://www.ab.gov.tr/index.php?p=45465\&l=1, E.T. 10.11.2017.

T.C. AB Bakanlığ1, http://www.ab.gov.tr/index.php?p=49043\&l=1, E.T. 10.11.2017.

Hacettepe University Journal of Economics and Administrative Sciences |

Vol 37, Issue 1, 2019

132 
T.C. AB Bakanlığ1, http://www.ab.gov.tr/index.php?p=49992\&l=1, E.T. 10.11.2017.

T.C. AB Bakanlığı, http://www.ab.gov.tr/index.php?p=45469\&l=1 E.T. 10.11.2017.

T.C. Dışişleri Bakanlığı, http://www.mfa.gov.tr/no_-230_-20-eylul-2016_-bosna-hersek_in-abadaylik-basvurusunun-kabuledilmesi-hk_.tr.mfa, E.T. 10.11.2017.

Türkekul, B., C. Günden, C. Abay, B. Miran (2010),“The Competitiveness of Turkish Olive Oil on the World Market", Journal of Food, Agriculture and Environment, 8(2), 68-73.

Utkulu, U., D. Seymen (2004), "Revealed Comparative Advantage and Competitiveness: Evidence for Turkey vis-a-vis the EU/15". Paper Presented on the European Trade Study Group 6th Annual Conference ETSG, Nottingham.

WTO, https://www.wto.org, E.T. 06.11.2017.

Wziatek KA. (2003), Critical Synthesis, Review of the Main Findings, Methodologies and Current Thought on Competitiveness of Accession Countries Mapping of Competence. Center for Socail and Economic Research. www.wto.org, E.T: 10.11.2017. 